\title{
Diagnostics of Natural Indicators of Ecological Safety of Rural Territories of the Region
}

\author{
A.A. Sidorov ${ }^{1, *}$, N.V. Lazareva $^{1}$, I.I. Firulina ${ }^{1}$ and $O . A$. Sapova $^{1}$ \\ *Corresponding author: sidorov120559@yandex.ru \\ ${ }^{1}$ Samara State University of Economics, Samara, Russia
}

\begin{abstract}
Ecological safety of the territory plays an important role in the socio-economic regional welfare. The goal of the research is to define the condition of ecological safety of the Samara region, a large region of Russia. The objectives of research cover the evaluation of natural (gross and specific) environmental indicators of natural-anthropogenic environment of rural municipal areas for the period 2014-2017. Materials for the calculations were official statistics. Methods of description, comparison, mathematical analysis, logical constructions have been applied. As a result, natural and anthropogenic environmental instability, the ambiguous situation in the subregions and unresolved problems in land use, forest use, air pollution, water use, water supply and wastewater disposal, and waste management were identified. It is proposed to use the results that were obtained in strategic planning and improvement of measures to ensure sustainable development of rural areas.
\end{abstract}

Keywords: environmental safety, conditions, emissions, waste, discharges.

\section{Introduction}

The security of the territory as a whole is based on its interrelated and mutually influencing components of natural and anthropogenic characteristics: economic, social, ecological, medical, food and other types. Ecological safety, as a basic condition for the protection of ecological interests of the population and natural environment, plays an important role in the socio-economic regional welfare. And, on the contrary, the level of economic security allows realizing successful environmental safety practices.

\section{Problem Statement}

A range of indicators are used for a comparative evaluation of the environmental safety of the areas [1], decisionmaking in the field of ecosystem services [2], integration of health, safety and environmental indicators [3], for ensuring social and environmental sustainability [4]. However, they are distinguished by the complexity of calculations, a number of significant disadvantages, therefore, for a comparative evaluation of subregions' condition in similar regions, natural (gross and specific) environmental indicators should be applied.

\section{Research Questions}

According to Agaeva \& Kurnosova, economic security in the Samara region is not sufficiently provided, information on which differs a little from macro-regional and federal parameters [5]. To ensure environmental safety in the region, from the point of view of A.V. Vasiliev [6], a lot of problems have to be solved therefore the constant monitoring and management support is required. It is known that the implementation of environmental safety is largely delegated to local municipal authorities, according to Federal Law No. 131 "On the General Principles of Organizing Local Self-Government in the Russian Federation" October 6, 2003 [7]. Environmental passports of municipal areas are made in the Samara region. There is such practice of creating specialized departments dealing with environmental issues in the structure of municipal administrations. So, the administration of municipal area Kinel-Cherkassky of the Samara region has the department of environmental control and environmental protection, the municipal program "Improving the environmental situation in the Kinel-Cherkassky area of the Samara region" is being implemented for 2016-2021. Thus, much data on environmental activities come from the municipal level to the regional one.

\section{Purpose of the Study}

The purpose of the research was to determine the condition of ecological safety of the Samara region, a large region of Russia. The objectives of the research included the evaluation of natural (gross and specific) environmental indicators of natural-anthropogenic environment of rural municipal areas for the period 2014-2017. 


\section{Research Methods}

The materials for the calculations were official statistics of the Ministry of Forestry, Nature Management and Environmental Protection of the Samara Region [8]. Methods of description, comparison, mathematical analysis, logical construction have been applied.

\section{Findings}

Regarding the global warming and increase of average air temperature the territory of the Samara region that is geographically located in the forest-steppe and steppe zone is experiencing a significant impact of sharp annual, seasonal and daily fluctuations of meteorological indicators (precipitation, temperature, humidity, etc.), otherwise this region is under greater instability of natural environmental conditions.

The distribution of water network in the region is highly uneven: it is relatively dense north of the Samara river and there are relatively rare and low-flow water flows to the south, which sometimes freeze out in the winter period and dry out in the summer. These crises result in the difficulties in water supply of the southern subregions.

Control of the ozone layer in the region showed that its total content (TO) ranges from 300 to $400 \mathrm{DU}(0.3-0.4 \mathrm{~cm})$, reaching the highest value in winter-spring period and the lowest one in autumn period. Along with this, there is the decrease in TO to pre-crisis conditions (the "ozone hole" is less than 220 DU), which always occured in November (263 DU - 1995, 265 DU - 2016, 266 DU - 2014). The annual amplitude of TOC fluctuation varied significantly from an average annual value: from $22 \%$ (2017) to $49 \%$ (2012).

The cadastre of greenhouse gases $\left(\mathrm{CO}_{2}, \mathrm{CH}_{4}, \mathrm{~N}_{2} \mathrm{O}, \mathrm{HFCs}, \mathrm{PFCs}, \mathrm{SF}_{6}\right)$ was created in the region for the first time in 2016. In total, their annual emissions reached more than 40 million tons of $\mathrm{CO}_{2}$, which is about $1.5 \%$ of the Russian scale taking into consideration the absolute dominance of $\mathrm{CO}_{2}(89.4 \%)$ and leaders of negative contribution of energy $(65 \%)$ and industrial $(24 \%)$ complexes. The absorption of greenhouse gases, calculated on the activities of forest vegetation, amounted to about 1.9 million tons of $\mathrm{CO}_{2}$, which does not exceed $5 \%$ of their release.

The radiation hygienic passport of the territory includes the results of periodic observations, which show the compliance of the environment radiation quality with the radiation safety standards with a background value of about $0.10-0.14 \mu \mathrm{Sv} / \mathrm{h}$. Local potentially dangerous technogenic sources of radiation pollution haven't been observed in big scales. At the same time, there is a certain threat from exogenous objects located in neighboring regions [9].

Large soil diversity is characterized by the availability of valuable black humus earth varieties. However, their current use has resulted in a steady trend of soil degradation, reduced land productivity, increased water and wind erosion, flooding, pollution, cluttering and other negative impacts. The humus content on average decreased to $4.22 \%$, and to the minimum values (3.15-3.3\%) in the Pestravsky, Bolshe-Chernigovsky, Khvorostyansky districts. Comprehensive monitoring of the state land according to legal documents has not been carried out for decades.

The low forest cover $(12.7 \%)$ of the region is characterized by significant variability of forest cover percentage (less than $2 \%$ in the south and $22-25 \%$ in the north). The objective of local forests is a protective function. The species distribution is not very diverse: oak (26\%), linden and aspen (17\% each), pine (14\%) and birch (10\%). They perform an important environmental, water protection, sanitary and hygienic, health-improving role. In strategic documents for the territory development, forest cover increase is not assumed.

The epidemiological situation according to the management of Rospotrebnadzor in the Samara region is considered as "satisfactory." With the significant reduction in infections, with the exception of infections of natural focal nature (hemorrhagic fever with renal syndrome, leptospirosis, etc., that focus West Nile fever) [10]. The spread of many diseases is associated with adverse environmental factors so medical and environmental problems are observed in the municipal districts of Bezenchuksky, Borsky, Kinelsky, Krasnoarmeysky and Neftegorsky [11].

The system of specially protected natural areas (PAs) in the region differs in the legal regime of their use: one object of international importance The Middle Volga complex biosphere reserve, three objects of federal importance: the Zhiguli State Natural Biosphere Reserve and two National parks (Samara Luka and Buzuluksky Bor), key ornithological territories: 7 of international and 8 of federal importance. 211 PAs of regional importance (nature monuments) have been created in the region. They occupy $1.78 \%$ (2017) in the total area of the region, and have a tendency to gradual increase (by 12.3\% since 1993). However, their subregional availability is extremely uneven, for example, the low proportion of PAs falls on Khvorostyansky (0.1\%), Elkhovsky, Krasnoarmeysky (0.2\% each), Klyavlinsky (0.3\%) districts and relatively high (4.4- 6.8\%) in Bezenchuk, Syzran and Kinel districts. The largest natural monument Krasnoarmeysky pine forest in Kinelsky district occupies more than 13 thousand hectares. At the same time, local PAs have not spread in the region.

1637777 legal entities and individual entrepreneurs are subject to regional environmental supervision in municipal areas. Their greatest number is registered in Sergievsky (405 units) and Volzhsky (393 units) districts. The smallest number is in Elhovsky (45 units) and Bolshe-Chernigovsky (50 units) districts, i.e. district indicators differ almost 8 times. 14,963 units of stationary pollution sources have been recorded in rural municipalities with an average number of 554 objects, which together create a gross emission of almost 140 thousand tons per year. At the same time, in some areas the number of stationary pollution sources is much less: in the Volga region there are only 61 objects or 9 times less than the average. The emissions into the atmosphere from stationary pollution sources on average (2017) per 1 permanent resident were 0.078 tons per year and 4.69 tons per year per $1 \mathrm{~km} 2$. Minimum emissions (less than 10 times) were observed in the 
Elkhovsky, Privolzhsky and Khvorostyansky areas. However, in the leading regions in terms of emissions (the BolsheGlushitsky, Bogatovsky and Kinelsky), the indicators exceed the average for the region by 6-10 times.

Large and small water bodies differ in the degree of pollution. Recently, a positive trend has been observed in the purification of small water bodies. So, river Padovka was considered as one of the most polluted water bodies in the river basin Volga and the most extremely dirty reservoir in the Samara region. Within 11 years of observing (since 2007), the water quality of the river has been rated as "extremely dirty" for 6 years, and in the other 5 years it was characterized as "dirty". Over the past 5 years, the highest pollution class was only once in 2015 , while for the previous five years the "extremely dirty" river was 4 times: in 2008 and three times in 2010, 2011, 2012. The largest water bodies of the region (Kuibyshev and Saratov reservoirs) are classified as "polluted", in some places "slightly polluted" with relative stability in the dynamics of improvement of some parameters [12].

In the general surface waters (about 65\%) dominate in the balance of domestic water supply, large-scale agglomerations of the region, and in 23 out of 27 municipal (85\%) districts water supply is provided at the expense of underground waters. The production and use of these waters is controlled to a certain extent, and the average annual water intake from natural sources is about $242 \mathrm{~m} 3$ / person. The largest water consumption is observed in the Elkhovsky (more than $1200 \mathrm{~m} 3$ per year / person) and Privolzhskii (more than $1100 \mathrm{~m} 3$ per year / person) districts. The minimum volumes (19-25 m3 per year / person) are consumed in Shentalinsky, Khvorostyansky, Isaklinsky, Kamyshlinsky, Borsky and Bolshe-Chernigovsky districts. There is a violation of drinking water quality to sanitary requirements: in $2015-25.3 \%$, $2016-17.9 \%, 2017-17.4 \%$ of underground sources, mainly due to the lack of water protection zones, and this is worse than the average in Russia. 11.7\% (2017) of water supply systems in the Samara region do not meet the sanitary and epidemiological requirements, while about $8 \%$ of them do not have appropriate waste treatment facilities, and necessary disinfecting facilities are not available on one water supply system.

The discharge of polluted wastewater into surface water bodies in the region averages over $155 \mathrm{~m} 3$ per year/person. However, the largest volumes of discharge are observed in the Elkhovsky district (about $900 \mathrm{~m} 3$ per year / person), almost 6 times more than the average for the region. Obviously, there is a violation of the control and accounting procedure. There are no data on wastewater discharges in the Krasnoarmeysky district; reporting documents provide data on zero discharges in the Bogatovsky, Bolshe-Glushitsky, Bolshe-Chernigovsky, Borsky, Pestravsky and Shentalinsky districts. The data on the number of water users that have wastewater discharges to surface water bodies varies greatly: if there are 10 units in the Krasnoyarskii district, there are 7 units in the Volzhsky district, there is only 1 water user in the Alekseevsky, Elkhovsky, Isaklinsky, Kamyshlinsky and other districts. The engineering facilities and networks have reached the limit of their using and repairing works are needed. If we compare the data of water consumption (242 m3) and discharge of polluted $(155 \mathrm{~m} 3)$ water, it turns out that, on average, $36 \%$ of the water consumed are cleaned up in the region to the required standards, without taking into account the irrigation and settlements that do not have centralized water supply.

The specific volume of waste generation in the region in average makes $1.28 \mathrm{t} /$ year per 1 inhabitant or $76.2 \mathrm{t} / \mathrm{km} 2$, with their maximum (more than 22 times more) accumulation in the Syzranskii district, a minimum (more than 10 times less) value makes in the Shigonsky, Privolzhsky, Pestravsky, Kamyshlinsky and Bolshe-Chernigovsky districts. The number of unauthorized (by the number of liquidated) landfill sites fluctuated by year: in $2013-427$, in $2014-275$, in 2015 - 218, in 2016 - 325, in 2017 - 1018 units, the largest ones in recent years are obviously connected with the "Year of Ecology" in the country and the mobilization of environmental work. According to the latest (2017) data there are no licensed landfill sites in 11 (40\%) municipal districts: Bezenchuksky, Bogatovsky, Bolshe-Chernigovsky, Borsky, Elkhovsky, Isaklinsky, Kamyshlinsky, Krasnoarmeysky, Pokhvistnevsky, Privolzhsky and Khvorostyansky. Obviously, the improvement of work in this area will be promoted by the Resolution of the Government of the Samara Region "On the Adoption of the State Program of the Samara Region“ Improvement of the Waste Management System, including Solid Municipal Waste in the Samara Region ” on the territory of the Samara Region”, on 2018-2022.

\section{Conclusion}

Analysis of the results of diagnostics of rural areas of the Samara region allows assessing the ambiguous state of environmental safety in the subregions, which can hardly be considered "satisfactory", with unresolved problems in land use, forest use, air pollution, water use, water supply and wastewater, waste management and others. The results can be used in strategic planning and measures improvement for sustainable development of rural areas.

\section{References}

1. W. Glinskiy, L. Serga, M. Khvan, K. Zaykov, The assessment methods of the level of countries environmental safety. Procedia Manufakturing, 21, 494-501. DOI: 10.1016/j.promfg.2018.02.149 (2018).

2. J. Hauck, C. Albert, C. Furst, D. Geneletti, D. La Rosa, C. Lorz, M. Spyra, Developing and applying ecosystem services indicators in decision-support at various scales. Ecological Indicators, 61, 1-5. DOI: 10.1016/j.ecolind.2015.09.037 (2016). 
3. M. Mapara, M.J. Jafaria, N. Mansouri, R. Arjmandi, R. Azizinejad, T.B.Ramos, Sustainability indicators for municipalities of megacities: Integrating health, safety and environmental performance. Ecological Indicators, 83, 271-291. DOI: 10.1016/j.ecolind.2017.08.012 (2017).

4. L. Mononen, A.-P. Auvinen, A.-L. Ahokumpu, M. Rönkä, N. Aarras, H. Tolvanen, M. Kamppinen, E. Viirret, T. Kumpula, P. Vihervaara, National ecosystem service indicators: Measures of social-ecological sustainability. Ecological Indicators, 61, 27-37. DOI: 10.1016/j.ecolind.2015.03.041 (2016).

5. L.K. Agaeva, E.A. Kurnosova, Assessment of the economic security of the Samara region. Science Vector of Togliatti State University. Series: Economics and Management, 3(30), 5-11 (2017). [in Rus.].

6. A.V. Vasiliev, Experience and problems of ensuring the environmental safety of urbanized territories (on the example of the Samara Region). In Low-waste, resource-saving chemical technologies and environmental safety: Collection of materials of the all-Russian scientific practical conference with international participation (pp. 281286). Sterlitamak: Printing House "Phobos" (2013).

7. Federal'nyj zakon «Ob obshchih principah organizacii mestnogo samoupravleniya v Rossijskoj Federacii» ot 06.10.2003 № 131 - FZ. Retrieved from: http://www.consultant.ru/document/cons doc LAW 44571/. Accessed: 23.01.2019 (2003). [in Rus.].

8. Ministry of forestry, environmental ptotection and nature management of the Samara region, State report "On the state of the environment and natural resources of the Samara region for 2014-2017". Retrieved from: http://www.priroda.samregion.ru. Accessed: 23.01.2019 (2017). [in Rus.].

9. A.A. Sidorov, I.S. Myamina, Potentially dangerous technogenic sources of radiation pollution in the Samara region. Samara Luka: Problems of Regional and Global Ecology, 25(4), 199-202 (2016). [in Rus.].

10. Office of Rospotrebnadzor in the Samara region, On the state of sanitary and epidemiological well-being in the Samara region in 2017. Annual report. Retrieved from: http://63.rospotrebnadzor.ru/documen/doclad. Accessed: 23.01.2019 (2017). [in Rus.].

11. M.L. Sirotko, Medico-demographic characteristics of the territory of the Samara region, taking into account the possible influence of environmental factors. News of the Samara Scientific Center of the Russian Academy of Sciences. Social, Humanitarian, Life Sciences, 16(5-2), 954-957 (2014). [in Rus.].

12. V.S. Tereshina, A.A. Sidorov, Analysis of the dynamics of the hydrobiological state of the Kuibyshev and Saratov reservoirs. Regional Development, 3(7). URL: https://cyberleninka.ru/article/n/analiz-dinamiki-gidrobiologicheskogosostoyaniya-kuybyshevskogo-i-saratovskogo-vodohranilischa. Accessed: 23.01.2019 (2015). [in Rus.]. 